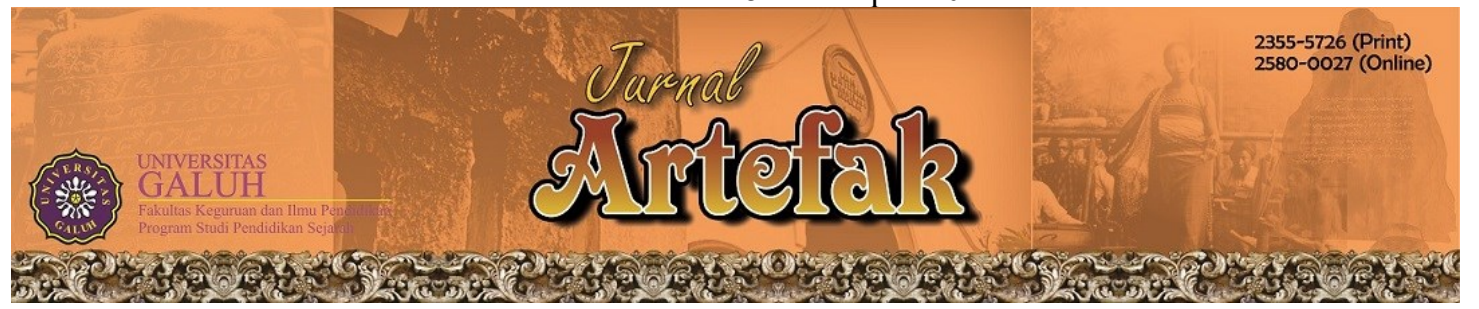

https://jurnal.unigal.ac.id/index.php/artefak/article/view/5087

\title{
PEMANFAATAN MUSEUM REMPAH \\ SEBAGAI SUMBER PEMBELAJARAN SEJARAH
}

\author{
Jamin Safi ${ }^{1}$ dan Suharlin Ode Bau ${ }^{2}$ \\ 1,2, Program Studi Pendidikan Sejarah, STKIP Kie Raha, Ternate, Indonesia \\ E-mail: jaminsafii@gmail.com ${ }^{1}$; odesuharlin@gmail.com ${ }^{2}$ \\ Sejarah Artikel: Diterima 1-Maret-2021 Disetujui 15-Maret-2021 Dipublikasikan -April-2021
}

\begin{abstract}
Abstrak
Tujuan penelitian ini adalah mendeskripsikan pemanfaatan museum rempah sebagai sumber pembelajaran, dampak perubahan, dan kendala-kendala pemanfaatan museum rempah dalam pembelajaran sejarah. Penelitian ini adalah penelitian kualitatif. Subjek penelitian ialah peserta didik dan guru sejarah di SMA Negeri 1 Ternate. Jenis sumber data meliputi guru sejarah dan peserta didik; tempat, peristiwa, arsip dan dokumen. Teknik pengumpulan data, yaitu wawancara, pengamatan, dan analisis dokumen. Pengujian keabsahan data penelitian dilakukan dengan cara triangulasi. Teknik analisis data penelitian menggunakan model interaktif meliputi reduksi data, penyajian data, dan penerikan simpulan. Penelitian ini menunjukan bahwa pemanfaatan museum rempah sebagai sumber pembelajaran sejarah dilakukan sekali waktu saja dan disesuiakan dengan materi pembelajaran. Dalam pelaksanaanya mengikuti tahapan-tahapan, yaitu: menentukan tujuan, menyusun rencana, membagi kelompok, penentuan judul, pelaksanaan, menyusun laporan, dan presentasi. Peserta didik mendapat informasi awal dari guru sebelum mengunjungi museum rempah. Dampak perubahan yang diperoleh adalah peserta didik menjadi aktif, berpikir kronologis, serta berpikir kesejarahan. Kendala pemenfaatan museum rempah sebagai sumber belajar adalah faktor waktu dan transportasi. Uapaya pemecahannya adalah dilakukan hanya dalam sekali waktu disesuaikan dengan kondisi pembelajaran disekolah.
\end{abstract}

Kata Kunci: Museum Rempah, Ternate, Sumber Pembelajaran Sejarah

\begin{abstract}
This research aims to describe the use of the spice museum as the learning source, its impact, and the obstacles in using it in the history study. This research employs qualitative method. The participants involved into this research are the students and the teachers of history of SMA Negeri 1 Ternate. The kind of data sources cover the history teachers and students; the place and events; and documentation. The researcher collects the data by using interviews, observations, and document analysis. The validity test towards the research data is done with triangulation. Meanwhile, the data is analyzed by applying interactive model: data reduction, data presentation, and conclusion. The result of this study shows that the use of the spice museum as the source of history study is done once and adapted to the learning material. The researcher accomplished the study through several phases: stating the purpose of the study, planning the study, grouping, theming, accomplishing, report writing, and presentation. The research shows that the students become more active in learning where they can think chronologically and historically. The obstacles found in the study in the spice museum are the limited time and transportation. The solution taken is to undertake the study once adapting with the learning condition in the school.
\end{abstract}

Keyword: The spice museum, Ternate, The source of history learning 


\section{PENDAHULUAN}

Pembelajaran sejarah di era melenial perlu menyesuaikan Perkembangan Ilmu Pengetahuan dan Teknologi Informasi. Perubahan paradigma pembelajaran dimaksudkan agar peserta didik dapat memahami kondisi sosial dan perkembangan zaman yang dihadapinya. Pembelajaran sejarah memiliki peran penting untuk membangun kesadaran historis. Peserta didik bukan hanya menghafal tahun, tokoh, dan tempat kejadian akan tetapi mampu memahami jati diri bangsa. Pembelajaran sejarah masa kini harus memberikan kesan positif. Untuk itu, setiap peristiwa sejarah harus diuraikan secara jujur, rinci, terstruktur dan sistematis.

Era teknologi informasi dan komunikasi dimana sumber pembelajaran sejarah sangat berlimpah, guru dan siswa memiliki peluang untuk mengajar dan belajar sejarah dengan kreatif. Guru bisa menggunakan metode tradisional melalui cerita sambil mengajak siswa berimajinasi ke zaman yang dipelajarinya. Guru dapat memfasilitasi siswa "berwisata" ke masa lalu untuk bermetafora dan melakukan tindakan-tindakan historis (Supriatna, 2019). Penggunaan metode tradisional dengan mengajak siswa mengunjui museum secara langsung akan lebih penting. Artinya, siswa dapat mengamati dan menganalisis setiap peninggalan sejarah yang disimpan dalam museum. Pembelajaran sejarah yang bersifat kontekstual dapat memberikan pengalaman nyata kepada siswa dalam merekonstruksi pengetahuan historis. Pembelajaran sejarah perlu ditemukan pada upaya pencarian makna dari sebuah peristiwa sejarah yang dikaitkan dengan nilai-nilai kehidupan (Sardiman, 2017).

Salah satu permasalahan yang diadapi dalam melaksanakan proses pembelajaran adalah partisipasi siswa dalam kegiatan belajar. Pembelajaran sejarah yang hanya fokus pada buku teks dan sistem kumunikasi satu arah menjadikan pembelajaran yang membosankan dan siswa tidak berpikir kritis terhadap setiap peristiwa sejarah. Pembelajaran sejarah dipandang sebagai aktivitas yang membosankan karena kerap diajarkan secara klasikal, yaitu menghafal atau sebagai pelajaran hafalan (Hamid, 2014).

Peristiwa sejarah masa lalu yang dipelajari berdasarkan sumber informasi yang tidak diciptakan sejarawan namun diciptakan orang lain, terdokumentasi, dan tersedia bagi sejarawan untuk dikaji serta direkonstruksi sebagai narasi sejarah (Hasan, 2019). Pembelajaran sejarah setidaknya harus mengajak siswa untuk mengamati tempat peristiwa secara langsung. Salah satunya adalah mendorong siswa untuk mengunjungi museum yang ada dilingkungan sekitarnya. Museum merupakan sumber penting dalam pembelajaran sejarah karena diketahui menyimpan objek sejarah dan budaya yang memberikan manfaat bagi dunia pendidikan terutama dunia pendidikan sejarah. Wasino (2007:19) menjelaskan bahwa sumber sejarah berdasarkan bentuknya dibagi menjadi tiga, yaitu sumber benda (bangunan, perkakas, senjata), sumber tertulis (dokumen), dan sumber lisan. Sumber sejarah menjadi begian penting bagi sejarawan atau peneliti sejarah. Peristiwa sejarah yang telah dirangkai menjadi tulisan sejarah penting untuk dipelajari. Selain itu, terdapat sumber sejarah berupa benda atau sumber tertulis yang tersimpan di museum yang dapat digunakan sebagai sumber pembelajaran sejarah di sekolah. Koleksi museum dapat digunakan sebagai media pembelajaran sejarah adalah koleksi yang bersifat visual dan tidak membosankan (Nuryanti et.al., 2018). Pemanfaatan museum rempah sebagai sumber belajar sejarah karena dapat membangkitkan semangat bagi siswa untuk belajar sejarah.

Uraian tersebut di atas, menjadi rujukan dilakukan penelitian tentang useum rempah 
sebagai sumber belajar. Penelitian ini mendeskripsikan tentang (1) Pemanfaatan museum rempah sebagai sumber pembelajaran sejarah di SMA Negeri 1 Ternate, (2) Dampak penggunaan museum rempah sebagai sumber pembelajarah sejarah (3) Kendala pemanfaatan musem rempah sebegai sumber pembelajaran sejarah.

\section{METODE PENELITIAN}

Penelitian tentang Pemanfaatan Museum Rempah Sebagai Sumber Pembelajaran Sejarah menggunakan metode kualitatif. Penelitian kualitatif merupakan prosedur penelitian yang mengahasilkan data deskriptif berupa kata-kata tertulis atau lisan dari orang-orang dan perilaku yang dapat diamati (Moleong, 2013). Untuk itu, dalam penelitian ini data yang dikumpulkan berupaka kata-kata tertulis atau lisan dan gambar sesuai dengan kondisi yang sebenarnya.

Penelitia ini dilaksanakan di SMA Negeri 1 Ternate. Data dan sumber data dalam penelitian ini yaitu peserta didik dan guru sejarah, tempat dan peristiwa berlangsungnya kegiatan pembelajaran sejarah dan arsip dan dokumen pendukung proses pembelajaran atau lainnya.

Teknik pengumpulan data dalam penelitian ini adalah wawancara, observasi dan analisis isi dokumen. Pada tahapan wawancara, peneliti menggali informasi secara lisan pada siswa dan guru sejarah untuk memperoleh informasi yang mendalam. Informasi tersebut berupa pemanfaatan museum rempah sebagai sumber pembelajaran sejarah. Selanjutnya observasi secara langsung untuk mengamati perilaku dan kativitas peserta didik dan guru dalam kegiatan pembelajaran. Studi dokumen merupakan aktivitas penelusuran terhadap dokumen dan arsip yang berhubungan dengan masalah penelitian kemudian dianalisis makna yang terkandung didalamnya.

Validitas data dengan menggunakan teknik triangulasi. Triangulasi dimaksudkan sebagai alat pembantu bagi peneliti (Denzim \& Lincoln, 2009). Triangulasi merupakan aktivitas pengujian validitas dengan tujuan memperoleh data/informasi yang benar. Mengingat triangulasi merupakan perangkat penting dalam penelitian maka dalam penelitian ini menggunakan triangulasi data/sumber dan metode. Triangulasi data diarakan untuk menggunakan beragam sumber data/informasi yang tersedia-artinya data sejenis, akan lebih baik kebenarannya apabila digali dari beberapa sumber data yang berbeda (Sutopo, 2006). Teknik ini digali melalui beberapa sumber data baik wawancara guru sejarah dan siswa, observasi langsung dan analisis dokumen pembelajaran sejarah. Data-data tersebut kemudian dibandingkan. Sedangakan triangulasi metode adalah pengecekan tingkat kepercayaan temuan hasil penelitian dilakukan dengan beberapa metode tetapi terarah pada data yang sejenis atau sama. Data atau informasi yang semula diperoleh dari dari wawancara kemudian dicek kembali dengan melakukan observasi langsung pada ketika kegiatan belajar.

Tahapan selanjutnya, taitu analisis data atau informasi yang telah dikumpulkan. Menurut Miles dan Huberman (Sugiyono, 2012) analisis data adalah aktivitas yang dilakukan secara interaktif dan berlangsung secara berulang-ulang sampai tuntas, sehingga datannya jenuh. Pada tahapan ini data/informasi dianalisi dengan menggunakan model interaktif dengan langkah-langkah antara lain adalah (1) reduksi data dilakukan dengan mengumpulkan semua data kemudian diseleksi, disederhanakan dan dikelompokan berdasarkan kemiripan informasi; (2) penyajian data merupaka suatu upaya untung menggabungkan informasi terkait dengan permasalahan penelitian. Penyajian 
data/informasi disusun bedasarkan pokokpokok yang terkait dalam reduksi data kemudian disajikan dengan menggunakan kalimat dan bahasa yang disusun secara logis dan sistematis serta mudah dipahami; dan (3) penarikan simpulan/verifikasi. Tahapan ini mencakup pemaknaan atau penafsiran terhadap data atau informasi yang terkumpul.

\section{HASIL PENELITIAN DAN PEMBAHASAN}

\section{Museum Rempah sebagai Sumber Pembelajaran Sejarah}

Museum merupakan sumber informasi dalam proses pembelajaran. Museum memiliki peran strategis dalam meningkatkan pengetahuan dan upaya pembangunan kesadaran sejarah dan karakter bangsa. Museum rempah di Ternate merupakan sumber belajar bagi siswa dalam mempelajari sejarah. Museum yang terletak di Benteng Orange, Ternate. Museum dibangun untuk menyimpan koleksi benda-benda sejarah dan budaya Ternate, Maluku Utara dan atau Indonesia. Selain tempat untuk menyimpan, merawat, dan mempertunjukan benda-benda peninggalan sejarah dan budaya, museum rempah juga sebagai tempat wisata dan pembelajaran bagi siswa, mahasiswa, dan masyarakat pada umumnya. Museum rempah bukan hanya tempat penyimpanan bendabenda sejarah dan budaya namun dapat dimanfaatkan sebagai sumber pembelajaran sejarah yang inovatif dan menyenangkan bagi pembelajar.

Pemanfaatan museum rempah sebagai sumber belajar sejarah di SMA Negeri 1 Ternate dapat mempermudah siswa memahami peristiwa dilingkungan sekitarnya. Dalam upaya meningkatkan pemahaman dan pengetauan sejarah tentang perkembangan imperialisme dan kolonialisme barat. Kompetensi dasar, yaitu menganalisis strategi perlawanan bangsa Indonesia terhadap penjajahan bangsa eropa hingga dengan abad ke- 20; dan menalar akibat politik, budaya, sosial, dan ekonomi, serta pembelajaran pada masa penjajahan bangsa eropa.

Museum rempah yang menyimpan benda bersejarah dapat dimafaatkan sebagai sumber belajar karena dapat memberikan pengalaman nyata bagi siswa tentang sejarah dilingkungannya. Peristiwa masa lalu daerah atau bangsa penting dipelajari dan dipahami untuk penguatan identitas bangsa. Pengembangan sumber pembelajaran tidak cukup hanya buku teks, akan tetapi perlu dioptimalkan nilai-nilai sosial dan budaya dilingkungan siswa seperti nilai nasionalisme (Syaharuddin at.al., 2019). Penguatan nilainilai patriotisme dan nasionalisme dapat mengajak siswa tempat peristiwa atau megunjungi museum menjadi penting karena siswa dapat memilih dan menentukan nilai yang menjadi patokan dalam kehidupan dalam setiap perubahan zaman.

Dalam pemanfaatan museum rempah sebagai sumber pembelajaran, guru mempertimbangkan faktor-faktor pendukung untuk dimuat dalam dalam rencana pembelajaran. Hal ini menjadi bagian penting dalam kegiatan di lapagan atau proses pembelajaran. Dalam memyusun rencana pembelajaran, guru sejarah berharap bahwa apa yang telah dipertimbangakan dalam menyusun rencana pembelajaran, proses dan hasilnya bisa maksimal. Perencanaan pembelajaran merupakan faktor penting. Untuk itu kegiatan pembelajaran diawali dengan guru menyusun rencana pelaksanaan pembelajaran, menyusun materi pembelajaran, dan menyiapkan video pebelajaran. Selain itu, guru juga mempertimbangkan model strategi, media dan sumber pembelajaran untuk menunjang kegiatan pembelajaran. Menurut Davis (2013) menjelaskan bahwa guru harus mempertimbangakan materi pembelajaran, 
cara untuk mengajarkannya, dan memastikan bahwa para siswa mempelajari apa yang diajarkan. Pelaksanakan pembelajaran yang dilakukan secara terencana dengan mempertimbangkan aspek-aspek penting dalam pembelajaran seperti materi, media dan sumber belajar, metode/strategi maka tujuan pembelajaran dapat tercapai. Berikut komponen pembelajaran yang harus diperhatikan dalam kegiatan pembelajaran:

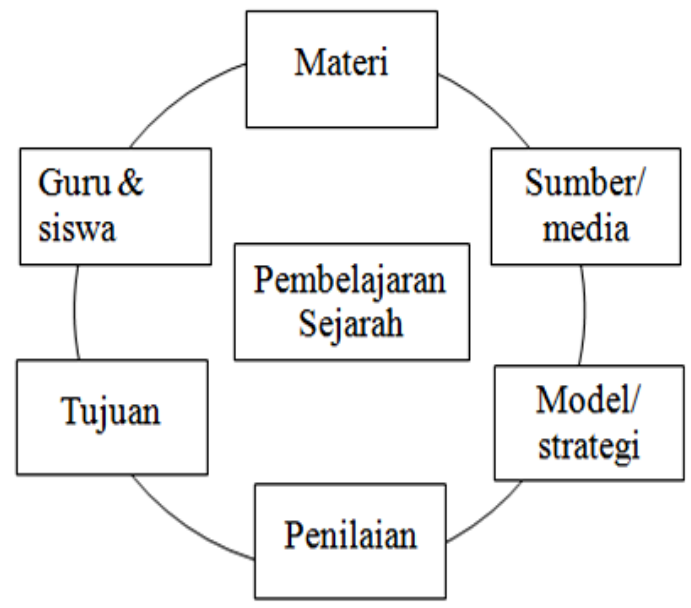

Gambar 1. komponen dalam kegiatan pembelajaran

Proes belajar di museum harus dipertimbangakan secara baik sebelum turun kelokasi. Ada beberapa hal penting yang perlu dipertimbangkan salam menyusun rencana adalah (1) menentukan tujuan (2) membagi siswa kedalam beberapa kelompok, (3) mempersiapkan instrumen observasi siswa, (4) menghubungi pihak museum tentang pelaksanaan kegiatan (Ahmad, 2010).

Rencana pelaksanaan pembelajaran telah memuat museum, benteng toluko, orange dan kalamata. Museum rempah yang terletak di dalam benteng orange mudah untuk diakses. Kegiatan pembelajaran dilakukan dengan mengikuti tahapan-tahapan antara lain kegiatan awal, inti dan kegiatan penutup. Pendekatan pembelajaran yang digunakan yaitu pendekatan ilmiah (scientifik approach). Kegiatan pembelajaran diawali yaitu guru menjelaskan sistem dan pendekatan pembelajaran yang digunakan sehingga setiap siswa yang mengikuti pembelajaran dapat memahaminya. Upaya pemanfaatan museum rempah sebagai media pembelajaran sejarah dilakukan dengan mempertimbangkan kapan waktu terbaik untuk dilaksanakannya. Praktek pembelajaran di museum rempah diawali dengan menyusun sebuah rencana yang matang sehingga pembelajaran menjadi menyenangkan.

Pemanfaatan museum rempah sebagai sumber pembelajaran disesuaikan dengan materi pembelajaran yaitu imperialime dan kolonialisme barat di Indonesia. Sebelum mengunjungi museum siswa memperoleh wawasan atau informasi dari guru tentang materi tersebut. Pembelajaran di museum rempah dilaksanakan sekali waktu yang sudah menjadi aganda rutin setiap semester. Hal-hal yang harus dipertimbangkan dalam pembelajaran di museum yaitu (1) pemanfaatan museum dilakukan sesekali waktu saja, (2) perlu pemberian materi awal sebelum mengunjungi museum (Ahmad, 2010).

Dalam prakteknya, wisata ilmiah ke museum rempah direncanakan dalam waktu khusus yang tidak menggangu aktivitas pembelajran di kelas. Kegiatan pembelajar dimuseum mengikuti tahapan-tahapan sebgai berikut (1) menentukan tujuan, (2) menyusun rencana, (3) pembagian kelompok, (4) penentuan judul kelompok, (5) pelaksanaan, (6) menyusun laporan, (7) presntasi.

Melalui museum rempah, siswa mencari informasi seperti melakukan pengamatan dan mencatat informasi tentang sebab-sebab bangsa eropa datang di Maluku, strategi perlawanan rakyat Maluku terhadap bangsa Portugis dan Belanda. Selain museum, benteng orange yang merupakan salah satu benteng peninggalan Belanda juga menjadi sember penting dalam mempelajari sejarah. Penggunaan metode wisata dalam pembelajaran sejarah juga dikolaborasi 
dengan metode pemberian tugas. Metode tugas, mendorong siswa untuk mencari informasi sesuai dengan permasalahan yang diberikan baik melalui internet dan melalukan pengamatan terhadap benteng-benteng peninggalan, yaitu benteng orange, benteng kalamata (santa lucia), dan kraton kesultanan Ternate. Pemanfaatan museum rempah/benteng orange dan atau bentenga peninggalan yang relevan dengan materi dapat berjalan efektif.

Pemanfaatan museum rempah dan atau bangunan peninggalan bersejarah membuat pembelajaran bermakna dan menyenangkan serta memberikan pengalaman nyata bagi siswa tentang sejarah dilingkungan sekitarnya. Keterlibatan siswa dengan lingkunagan sekitar membantu mereka untuk memahami materi dan makna yang terkandung didalamnya (Wijayanti, 2017).

Selain itu, siswa dapat mengenal secara langsung benda-benda sejarah dan sejarah tokoh-tokoh pahlawan yang ikut berjuangan melawan penjajah. Siswa juga dapat mengetahui bahwa rempah-rempah seperti cengke dan palah menjadi faktor penting yang mendorong bangsa-bangsa barat berlayar ke Maluku (Bacan, Makeang, Tidore, Ternate, Moti, dan Jailolo). Menurut Winerburg (2006:33) bahwa setiap peristiwa sejarah harus diikuti penjelasan yang kontekstual, yaitu merajut, menjalin ikut serta dalam proses untuk menghubungkan hal-hal suatu sama lain yang menjadi suatu pola.

\section{Dampak Pembelajaran Sejarah bagi Peserta Didik}

Pembelajaran sejarah dengan pemanfaatan museum sebagai sumber pembelajaran membangkitkan semangat perta didik. Hal ini juga sampaikan Kochar (2008) sumber belajar merupakan sarana pembelajaran yang sangat penting untuk memperluas konsep dan membangkitkan minat siswa.
Pembelajaran sejarah melalui pemanfaatan museum rempah atau situs-situs sejarah adalah meningkatkan pemahaman historis, terampil dalam memanfaatkan sumber-sumber, dan kesadaran terhadap lingkungan sosila dan budaya dalam setiap perubahan zaman. Isjoni (2007:55) menjelaskan bahwa mempelajari sejarah berarti melihat gambaran nyata tetang perjalanan kehidupan manusia dalam menunjukan adanyan suatu perubahan sebagai hasil aktivitas sosial, politik, dan kebudayaan. Setiap peserta didik mengungkapkan bahwa belajar langsung dengan mengunjungi museum dan atau mengamati langsung situs sejarahnya lebih efektif dan menyenangkan. Masa lalu yang direkonstusi bukan hanya menambah pengetahuan sejarah akan tetapi dapat menginstropeksi diri sebagai generasi bangsa untuk melihat masa depan lebih baik. Melalui peristiwa masa lalu, siswa dapat meneladani nilai-nilai karakter kepahlawanan , yaitu nasionalisme,patriotisme, dan nilainilai sosial sebagai upaya peningkatan karakter kebangsaan. Menurut Rowse (2014) menjalaskan bahwa guna mempelajari sejarah adalah untuk masa depan yang lebih baik.

Pembelajaran dengan memberi pengalaman nyata mendorong peserta didik menyadari betul semangat perjuangan para pahlawan baik lokal maupun nasional dalam memperjuangankan nasib bangsa. Dalam setiap perjuangan bahkan ada yang sempat menikmati dan tidak sempat menikmati buah dari perjuangan mereka karena gugur dalam medan pertempuran. Nilai-nilai Nilai-nilai peruangan para pahlawan seperti seperti nasionalsme, patriotisme, dan cintah tanah air telah membuka pikiran dan hati siswa untuk diteladani dalam upaya pembangunan karakter dan identitas bangsa. Menurut Kochar (2008) bahwa pembelajaran sejarah secara tepat adalah salah satu cara terbaik dalam menciptakan identitas bangsa dalam diri siswa. Pemanfaatan museum dan atau situs- 
situs sejarah dilingkungan sekiranya dapat mendorong kemampuan berpikir kesejarahan ((historical thinking).

\section{Kendala yang dihadapi dalam Pembelajaran Sejarah}

Kendala waktu dan transportasi menjadi kendala dalam kegiatan pembelajaran dilapangan baik mengunjungi museum, kraton, dan atau bangunan-bangunan peninggalan sejarah. Hal ini juga dihadapi dalam pembelajaran sejarah dengan pemanfaatan museum dan atau situs sejarah lainnya seperti benteng dan keraton. Untuk meminimalisir kendala-kendala tersebut, pelaksanaan pembelajaran dilapangan dilakukan hanya sekali waktu dan dibicarakan bersama dengan peserta didik. Selain itu, benda peninggalan yang tidak sempat diobservasi tetapi relevan dengan materi pelajaran didesain dalam bentuk gambar dan video untuk disajikan dalam kegiatan pembelajaran kelas melalui LCD. Penyusunan buku ajar yang disajikan dalam bentuk gambar dan diikuti dengan penjelasan guru tentang peristiwa sejarah memudahkan siswa memahami materi yang disajikan.

\section{KESIMPULAN}

Museum rempah merupakan sumber belajar sejarah. Proses pembelajaran dengan mengajak siswa mengunjugi museum membuat pembelajaran sejarah lebih menyenangkan. Kegiatan tersebut merupakan bagian dari belajar sambil berwisata sejarah. Dalam kegiatan belajar di museum rempah, siswa dapat mengamati secara langsung tentang gambar dan atau benda-benda di museum. Dalam praktik pembelajaran sejarah dengan menggunakan museum rempah dilakukan sekali waktu dalam setiap semester. Pembelaaran sejarah di SMA Negeri 1 Ternate dengan menfaatan museum rempah dilakukan dengan mengikuti skema pembelajaran antara lain menentukan tujuan, menyusun rencana pembelajaran di museum, membagi kelompok, memberi judul/atau masalah, pengamatan, penyusunan laporan dan presentasi hasil laporan.

Dampak pemanfaatan museum rempah dan situs sejarah sebagai sumber belajar, yaitu siswa lebih aktif mengamati dan mencatat setiap informasi sesuai dengan permasalahan yang diberika oleh guru. Pembelajaran sejarah dengan mengajak siswa ke museum atau tempat bersejarah dapat memberikan pengalaman historis dan meningkatkan keterampilan berpikir kesejarahan. Sedangkan kendala yang dihadapi dalam kegiatan pembelajaran adalah waktu karena jadwal pebelajaran di sekolah yang padat. Upaya yang dilakukan guru dalam meminimalisir kendala tersebut adalah dibibahas bersama siswa untuk menentukan waktu terbaik pembelajaran di lapangan.

\section{DAFTAR PUSTAKA}

Ahmad, T. A. (2010). Strategi Pemanfaatan Museum sebagai Media Pembelajaran pada Materi Zaman Prasejarah. Paramita, 20(1), 105-115. https://journal.unnes.ac.id/nju/index.ph p/paramita/article/viewFile/1092/1002

Davis, Barbara Gross. (2013). Perangkat Pembelajaran (Teknik Mempersiapkan dan Melaksanakan Perkuliahan yang Efektif). Jakarta: Rajawali Pers.

Denzim, Norman K \& Lincoln, Yvonna S. (2009). Handbook of Qualitative Research. Yogyakarta: Pustaka Pelajar. Hamid, Abd. Rahman. (2014). Pembelajaran Sejarah. Yogyakarta: Ombak.

Hasan, S. H. (2019). Pendidikan Sejarah Untuk Kehidupan Abad ke 21. HISTORIA: Jurnal Pendidik Dan Peneliti Sejarah, II (2), 61-72. 
https://ejournal.upi.edu/index.php/histo ria/article/view/16630

Isjoni. (2007). Pembelajaran Sejarah Pada Satuan Pendidikan. Bandung: Alfabet.

Kochar, S.K. (2008). Pembelajara Sejarah: Teaching of History. Jakarta: Grasindo.

Moleong, Lexy. (2013). Metodologi Peneltian Kualitatif. Bandung: Remaja Rosda Karya.

Nuryanti at.al. (2018). Museum Sebagai Sumber Pembelajaran Sejarah: Studi Situs Pada Museum Jawa Tengah Ranggawarsito Semarang. Pawiyatan, XXI(2), 91-99.

http://e-

journal.ivet.ac.id/index.php/pawiyatan/ article/view/737/664.

Rowse, A.L. (2014). Apa Guna Sejarah?. Jakarta: Komunitas Bambu.

Sardiman, A. (2017). Reformulasi Pembelajaran Sejarah: Sebuah Tantangan. Istoria: Jurnal Pendidikan Dan Sejarah, 12 (2), 12-20.

https://journal.uny.ac.id/index.php/istor ia/article/view/17610

Supriatna, N. (2019). Pengembangan Kreativitas Imajinatif Abad Ke-21 Dalam Pembelajaran Sejarah. Historia: Jurnal Pendidik Dan Peneliti Sejarah, II (2), 73-82.

https://ejournal.upi.edu/index.php/histo $\mathrm{ria} /$ article/view/16629

Sugiyono. (2012). Metode Penelitian Kuantitatif, Kualitatif, dan $R \& D$. Bandung: Alfabeta.

Sutopo, H. B. (2006). Metodologi Penelitian Kualitatif: Dasar Teori dan Terapannya dalam Penelitian. Surakarta: Universitas Sebelas Maret.

Syaharuddin, Heru Puji Winarso, A. H. (2019). Nilai-Nilai Nasionalisme Perjuangan Hassan Basry Sebagai Sumber Belajar Sejarah. Jurnal Pendidik Dan Peneliti Sejarah, II (2), 91-96. https://ejournal.upi.edu/index.php/histo ria/article/view/16632

Wasino. (2007). Dari Riset Hingga Tulisan Sejarah. Semarang: UNNES Press.

Wijayanti, Y. (2017). Peranan Penting Sejarah Lokal Dalam Kurikulum di Sekolah Menengah Atas. Jurnal Artefak, 4(1), 53-60.

https://jurnal.unigal.ac.id/index.php/art efak/article/view/735

Winerburg, Sam. (2006). Berpikir Historis. Jakarta: Yayasan Obor Indonesia. 